\title{
GAME EDUKASI BAHASA INGGRIS MENGGUNAKAN METODE GOAL DIRECTED DESIGN
}

\author{
Evanny Christianisa ${ }^{1}$ \\ evanny_cl@yahoo.com
}

\author{
Rosa Delima ${ }^{2}$ \\ rosadelima@ukdw.ac.id
}

\author{
Theresia Herlina R. ${ }^{3}$ \\ herlina@ukdw.ac.id
}

\begin{abstract}
Education game is a media used as a learning tool. In this research, we built a learning application of animal and fruit names vocabulary in English. Users of the application are 4 to 6 years old children. The purpose of this research is to build an application that can improve children's ability to remember and enrich their Vocabulary. For the user interface design we implement Goal Directed Design Method. This Method consists of eight main stages, which is research, modeling, requirements, definition, framework definition, refinement, and support. Participants of this research were 18 children aged 4 to 6 years. Based of the evaluation of the application, all participants are able to increase their ability to remember animal and fruit names by about $10 \%$.
\end{abstract}

Kata kunci : Education Game, GDD Method, Goal Directed Design Method, Human Computer Interaction, Children Application.

\section{Pendahuluan}

Bahasa Inggris merupakan bahasa asing yang penting untuk dikuasai oleh publik agar dapat berkomunikasi di dunia global ini. Ada banyak cara untuk mengenalkan bahasa Inggris bagi anak, misalnya dengan buku, film, atau game edukasi. Game edukasi merupakan media yang populer saat ini. Tidak hanya sebagai media hiburan, tetapi juga sebagai media alternatif pembelajaran. Game edukasi dapat membantu proses pendidikan bagi anak untuk membentuk citra baru bahwa belajar begitu menyenangkan.

Dalam pembuatan game edukasi khususnya bagi anak, perlu memperhatikan desain antarmuka supaya menarik seperti bentuk visual, warna, audio. Pada penelitian ini akan digunakan metode Goal Directed Design untuk perancangan dalam pembuatan game edukasi. Konsep dari Goal Directed Design adalah menekankan tujuan pengguna dalam mendesain sebuah antarmuka, sehingga diharapkan sistem yang dibuat akan dapat digunakan dengan mudah oleh anak.

Tujuan dari penelitian ini adalah merancang game edukasi yang dapat meningkatkan jumlah kosakata nama hewan dan buah dalam bahasa Inggris yang mampu diingat oleh pengguna.

\section{Teori Pendukung}

\subsection{Metode Goal Directed Design}

Metode Goal Directed Design dikembangkan oleh Alan Cooper, konsep dari Goal Directed Design adalah menekankan tujuan pengguna dalam mendesain sebuah antarmuka, sehingga diharapkan sistem yang dibuat akan dapat digunakan dengan mudah. Menurut Alan, Reimann, \& Cronin (2007) tampilan akhir dari sistem dengan menggunakan Goal Directed

\footnotetext{
${ }^{1}$ Teknik Informatika, Fakultas Teknologi Informasi, Universitas Kristen Duta Wacana

${ }^{2}$ Teknik Informatika, Fakultas Teknologi Informasi, Universitas Kristen Duta Wacana

${ }^{3}$ Teknik Informatika, Fakultas Teknologi Informasi, Universitas Kristen Duta Wacana
} 
Design ini didasarkan pada tujuan pengguna dan kebutuhan pengguna. Terdapat enam tahap dalam Goal Directed Design yaitu research, modeling, requirements definition, framework definition, refinement dan support.

\section{Research}

Pada tahap ini dilakukan observasi, wawancarara dan evaluasi perangkat lunak yang berada pada domain yang sama dengan sistem yang akan dibangun. Hasil dari tahap ini berupa data kualitatif mengenai pengguna dari sistem.

\section{Modeling}

Pada tahap modeling akan dilakukan analisis data yang didapatkan pada tahap sebelumnya. Sehingga akan dihasilkan model pengguna/persona, model pengguna adalah gambaran perilaku, tujuan pengguna dan interaksi dengan pengguna lainnya.

\section{Requirements Definition}

Pada tahap ini akan menganalisis model pengguna dan kebutuhan fungsional yang berfokus pada sekenario. Hasil dari tahap ini adalah definisi persyaratan yang menyeimbangkan pengguna, bisnis, dan persyaratan teknis dari desain.

\section{Framework Definition}

Pada tahap ini akan membuat konsep produk secara keseluruhan, mendefinisikan kerangka dasar untuk perilaku produk dan desain visual. Hasil dari proses ini adalah definisi kerangka interaksi, konsep desain yang stabil tetapi masih dalam bentuk kasar.

5. Refinement

Tahap Refinement mirip dengan tahap Framework Definition, tetapi pada tahap ini lebih meningkatkan fokus pada detail dan implementasi. Mendefinisikan styles sistem, ukuran, icon, dan elemen visual lainnya yang memberikan pengalaman yang menarik dengan hasil yang jelas dan hirarki visual. Puncak dari tahap refinement adalah dokumentasi rinci dari desain, bentuk dan perilaku spesifik.

6. Support Development

Walaupun solusi desain sudah disusun dengan baik, namun masih dimungkinkan untuk munculnya pertanyaan-pertanyaan dan tantangan lain dari para pengembang.

\section{Analisis}

\subsection{Penerapan Goal Directed Design}

Dalam merancang desain antarmuka game edukasi yang dibangun, digunakan metode Goal Directed Design. Penelitian ini dilakukan di TK BOBKRI Gondokusuman. Pada tahap research, wawancara dilakukan kepada guru bahasa Inggris di TK BOPKRI dan psikolog, sedangkan responden dari kuisioner yang dibagikan adalah orang tua siswa TK BOPKRI yang berjumlah 30 responden. Pada saat pengujian, partisipan merupakan 18 siswa di TK BOPKRI yang berumur 4-6 tahun. Hasil yang didapatkan pada tahapan Goal Directed Design dalam membangun aplikasi yaitu:

\section{Research}

Pada tahap pertama dalam Goal Directed Design, dihasilkan Experience Goals dan End Goals. Experience Goals pada penelitian ini adalah aplikasi mudah digunakan dan membuat belajar kosakata Bahasa Inggris menjadi lebih menyenangkan. Sedangkan End Goal pada penelitian ini adalah meningkatkan jumlah kosakata nama hewan dan buah dalam bahasa Inggris yang mampu diingat oleh pengguna.

\section{Modeling}

Pada tahap Modeling dihasilkan persona, yang memiliki tujuan mampu meningkatkan jumlah kosakata nama hewan dan buah dalam bahasa. Karakteristik persona tersebut adalah sebagai berikut: 
- $\quad$ Murid TK B

- Lama menggunakan gadget 1-2 jam perhari

- Menggunakan gadget tersebut untuk bermain Angry Bird

- Belum bisa membaca kata Bahasa Inggris

- Belum bisa menulis kata Bahasa Inggris

3. Requirement Definition

Pada tahap Requirement Definition diperoleh problem statements yaitu pengguna dapat memahami mengenai kosakata nama hewan dan buah dalam bahasa Inggris. Dan vision statements yaitu membuat aplikasi yang menyenangkan sehingga dapat belajar kosakata nama hewan dan buah dalam bahasa Inggris.

4. Framework Definition

Pada tahap Framework Definition dilakukan dengan membuat konsep produk secara keseluruhan, mendefinisikan kerangka dasar untuk perilaku produk dan desain visual. Pada tahap ini disusun hirarki aplikasi yang adakan dibangun, seperti yang ditujukan pada gambar 1 .

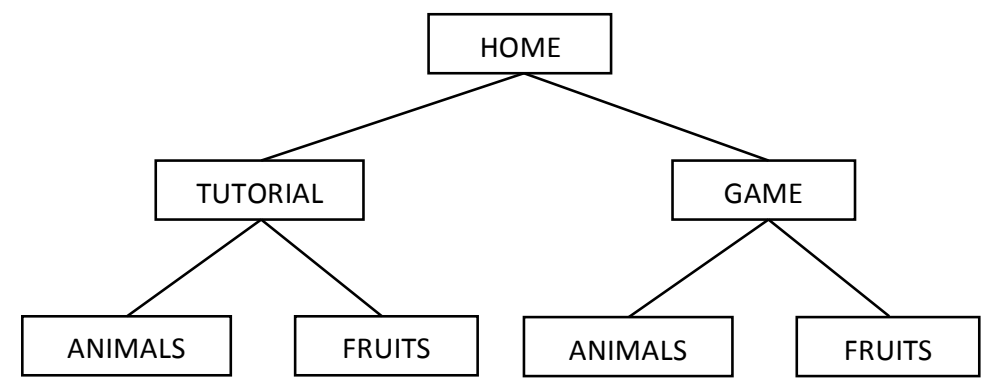

Gambar 1. Hirarki Aplikasi yang akan dibangun

\section{Refinement}

Tahap Refinement merupakan implementasi dari tahap Framework Definition dalam bentuk nyata. Bagian-bagian yang ada di dalam aplikasi ini adalah sebagai berikut:

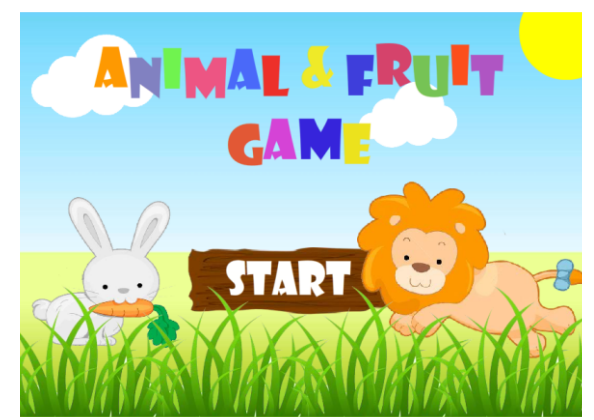

Gambar 2. Halaman Awal

Ketika pertama kali pengguna membuka aplikasi ini, maka akan muncul halaman awal seperti pada gambar 2. Pada halaman ini terdapat satu tombol yaitu 'start' yang berfungsi untuk memulai aplikasi ini dan akan menuju ke halaman menu. Pada halaman menu terdapat pilihan 'Let's Learn' dan 'Let's Play'. Jika Pengguna memilih 'Let's Learn', maka akan ada pilihan topik 'Animal' dan 'Fruit'. Kedua topik materi tersebut berisi gambar-gambar hewan atau buah seperti pada gambar 3, yang apabila dipilih akan menampilkan informasi mengenai objek yang dipilih. 


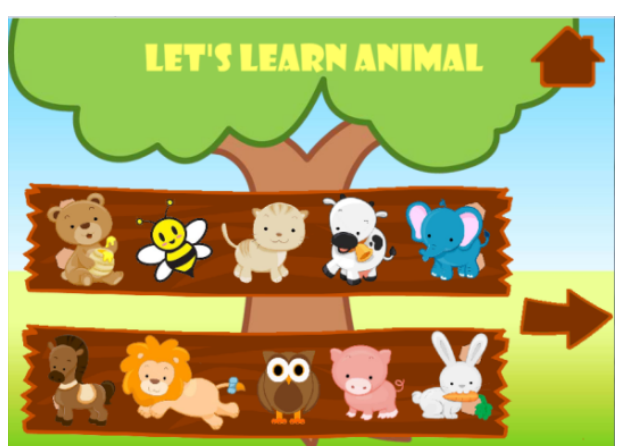

(a)

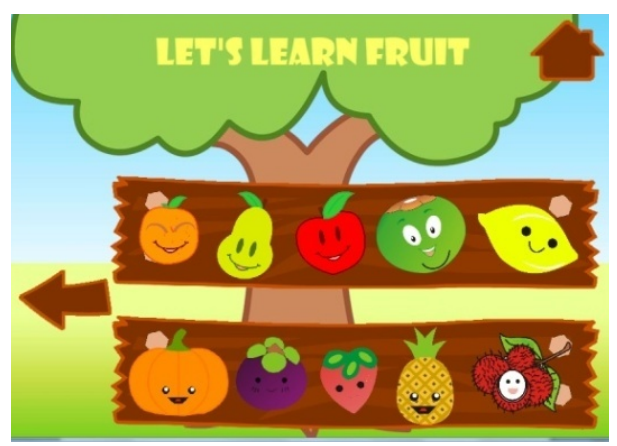

(b)

Gambar 3 Halaman 'Let's Learn’

Ketika pengguna memilih objek yang diinginkan, maka akan muncul animasi hewan atau buah (seperti gambar 4) sesuai dengan objek yang dipilih oleh pengguna yang disertai dengan audio nama hewan/buah tersebut dalam bahasa Indonesia dan bahasa Inggris yang disertai dengan suara hewan tersebut. Pada halaman ini terdapat 3 tombol, tombol 'previous', 'repeat' dan 'next'. Tombol 'previous' akan mengantarkan pengguna ke objek sebelumnya, tombol 'repeat' untuk mengulang kembali objek yang sedang ditampilkan, dan tombol 'next' untuk menuju ke objek berikutnya.

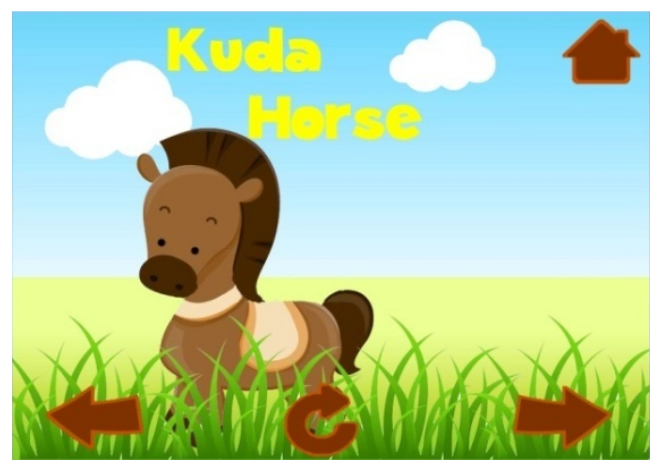

(a)

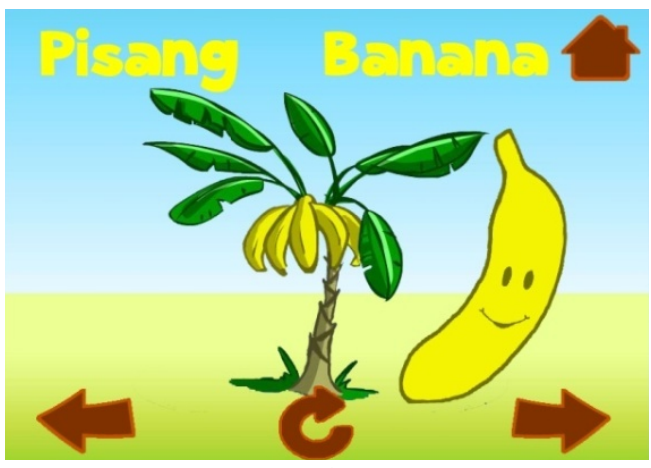

(b)

Gambar 4 Halaman 'Animal' dan 'Fruit'

Pada menu 'Let's Play' terdapat 2 jenis permainan pada masing-masing topik (hewan dan buah) yaitu 'Find Animal/Fruit Name' dan 'Find Animal/Fruit'. Pada halaman 'Find Animal/Fruit Name' seperti pada gambar 5(b), pengguna diminta unruk mencari nama dari hewan/buah yang ditampilkan pada setiap pertanyaan yang diberikan berupa audio "what is this animal/fruit name?". Pengguna dapat menekan tombol play yang terdapat di bawah pilihan jawaban. Tombol play tersebut akan mengeluarkan audio pilihan nama hewan dalam bahasa Inggris. Pengguna tinggal memilih kata yang berada di atas tombol play yang dianggap benar.

Pada halaman 'Find Animal/Fruit' seperti pada gambar 5(b), pengguna diminta untuk mencari hewan/buah yang diminta oleh sistem yang berupa audio contohnya "let's find Sheep". Pengguna memilih jawaban yang dianggap benar dengan cara memilih hewan tersebut. Pada halaman permainan ini terdapat skor yang menampilkan perolehan poin yang telah diperoleh pengguna. Apabila pengguna ingin mengulangi pertanyaan, pengguna dapat menekan tombol 'repeat'. Jika pengguna berhasil menjawab pertanyaan tersebut dengan benar, maka skor akan bertambah. 


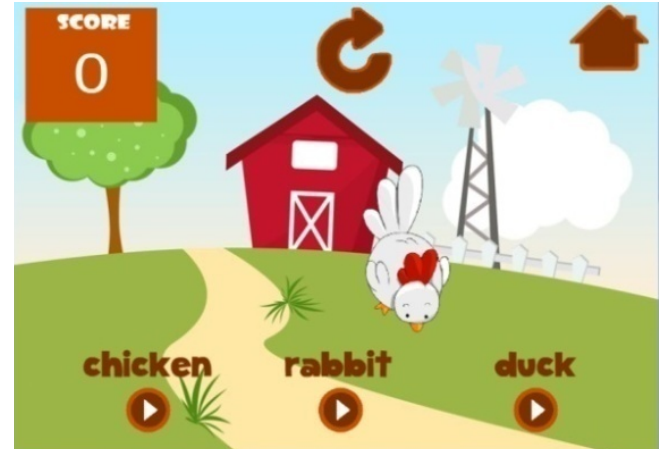

(a)

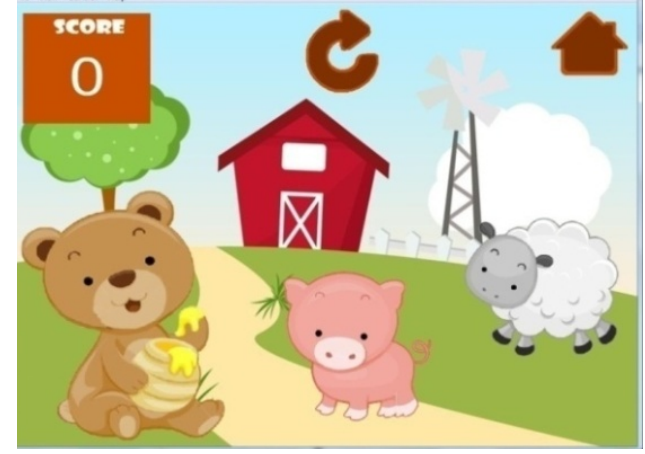

(b)

Gambar 5 Halaman 'Find Animal/Fruit Name' dan 'Find Animal/Fruit'

Apabila pengguna menjawab dengan benak maka akan muncul tampilan 'CORRECT! VERY GOOD' seperti pada gambar 6(a), sebaliknya jika pengguna salah menjawab pertanyaan, maka skor tidak akan bertambah dan akan muncul tampilan 'WRONG!' dan aplikasi akan menunjukkan jawaban yang benar seperti pada gambar 6(b).

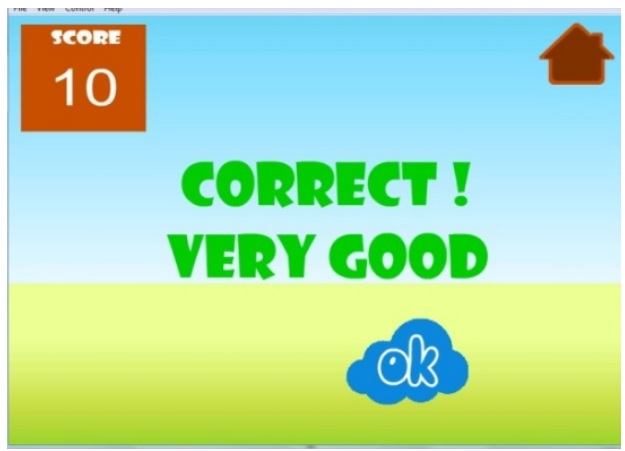

(a)

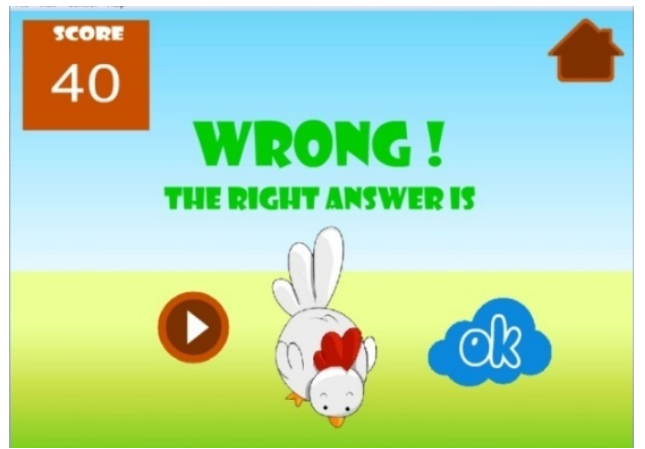

(b)

Gambar 6 Halaman Salah dan Halaman Benar

Apabila pengguna telah menjawab 10 pertanyaan, maka permainan telah berakhir dan akan ditampilkan skor akhir yang telah dicapai pengguna. Pada halaman ini juga terdapat tombol untuk mengulangi permainan ini lagi.

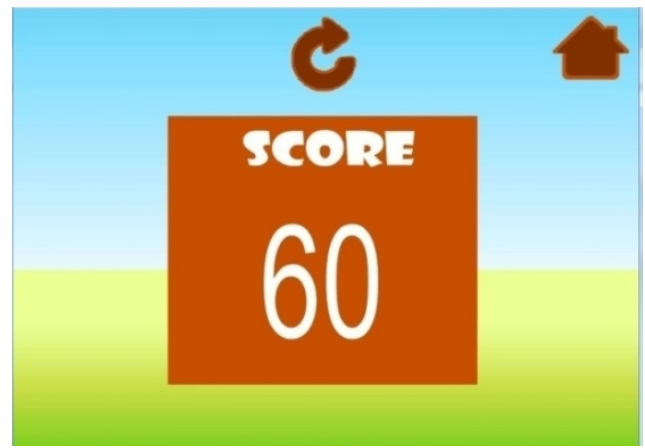

Gambar 7 Halaman 'Game Over'

\subsection{Evaluasi Sistem}

Partisipan pada pengujian ini, berjumlah 18 orang siswa. Partisipan dibagi menjadi 2 kelompok, yang pertama menggunakan aplikasi sebanyak 3 kali dan yang kedua menggunakan aplikasi 1 kali. Kedua kelompok partisipan terlebih dahulu diberikan 20-pertanyaan dengan menunjukkan 10 gambar hewan dan 10 gambar buah dan partisipan diminta untuk menjawab bahasa Inggris dari gambar yang ditunjukkan. 
Berdasarkan data hasil pengujian tidak terjadi penurunan pengetahuan kosakata bahasa Inggris yang diuji pada seluruh partisipan kelompok 1. Pada percobaan pertama, hanya Ishak yang tidak mengalami peningkatan pengetahuan kosakata, sedangkan partisipan lainnya yaitu Rasti, Tiun, Thania, Nunsi, Michiko, Ajeng, Nathan, dan Nael mengalami peningkatan.

Dari hasil 3 percobaan yang telah dilakukan pada kelompok 1, partisipan rata-rata mengalami peningkatan sebanyak 2 pertanyaan yang dapat dijawab di setiap percobaan. Artinya setelah menggunakan aplikasi, partisipan bertambah pengetahuan kosakata nama hewan dan buah dalam bahasa Inggris sebanyak 2 kosakata.

Tabel 1.

Rekapitulasi Selisih Jawaban Benar dari Kelompok 1 pada 3 Percobaan

\begin{tabular}{|c|l|c|c|c|}
\hline \multirow{2}{*}{ No. } & \multirow{2}{*}{ Nama } & \multicolumn{3}{|c|}{ Selisih Jawaban Benar dengan Percobaan } \\
\cline { 3 - 5 } & & $\mathbf{1}$ & $\mathbf{2}$ & $\mathbf{3}$ \\
\hline & & 1 & 4 & 4 \\
\hline 1. & Rasti & 2 & 3 & 2 \\
\hline 2. & Tiun & 3 & 2 & 1 \\
\hline 3. & Thania & 0 & 1 & 2 \\
\hline 4. & Ishak & 2 & 2 & 2 \\
\hline 5. & Nunsi & 2 & 3 & 3 \\
\hline 6. & Michiko & 2 & 2 & 4 \\
\hline 7. & Ajeng & 3 & 1 & 0 \\
\hline 8. & Nathan & 3 & 4 & 3 \\
\hline 9. & Nael & $\mathbf{2}$ & $\mathbf{2 , 4 4}$ & $\mathbf{2 , 3 3}$ \\
\hline & Rata-rata & & & \\
\hline
\end{tabular}

Sama seperti kelompok 1, pada kelompok 2 juga diminta untuk menjawab 20 pertanyaan kosakata nama hewan dan buah yang sama dengan kelompok 1. Pada kelompok 2, partisipan hanya menggunakan aplikasi sebanyak 1 kali selama 10 menit. Setelah menggunakan aplikasi, partisipan kembali diberi pertanyaan yang sama.

Tabel 2.

Rekapitulasi Selisih Jawaban Benar Sebelum dan Sesudah Menggunakan aplikasi dari Kelompok 2

\begin{tabular}{|c|l|c|}
\hline No. & \multicolumn{1}{|c|}{ Nama } & Selisih Jawban Benar \\
\hline 1. & Jonas & 3 \\
\hline 2. & Aldi & 1 \\
\hline 3. & Listia & 3 \\
\hline 4. & Enjel & 3 \\
\hline 5. & Rio & 4 \\
\hline 6. & Asa & 1 \\
\hline 7. & Lony & 1 \\
\hline 8. & Lintang & 1 \\
\hline 9. & Kezia & $\mathbf{2 , 2 2}$ \\
\hline \multicolumn{2}{|l}{} \\
\hline
\end{tabular}

Penilaian aspek Learnability diperoleh dengan membandingkan hasil sebelum partisipan menggunakan aplikasi dengan sesudah menggunakan aplikasi. Seperti pada gambar 8 dari setiap percobaan ke percobaan selanjutnya rata-rata partisipan mengalami peningkatan. Rata-rata peningkatan pertanyaan yang dapat dijawab partisipan dari sebelum menggunakan aplikasi sampai menggunakan aplikasi sebanyak di setiap percobaan adalah 2 pertanyaan. 
Pada pengujian yang dilakukan pada kelompok 1, yang telah memakai aplikasi sebanyak 3 kali, diperoleh hasil peningkatan seperti dibawah ini:

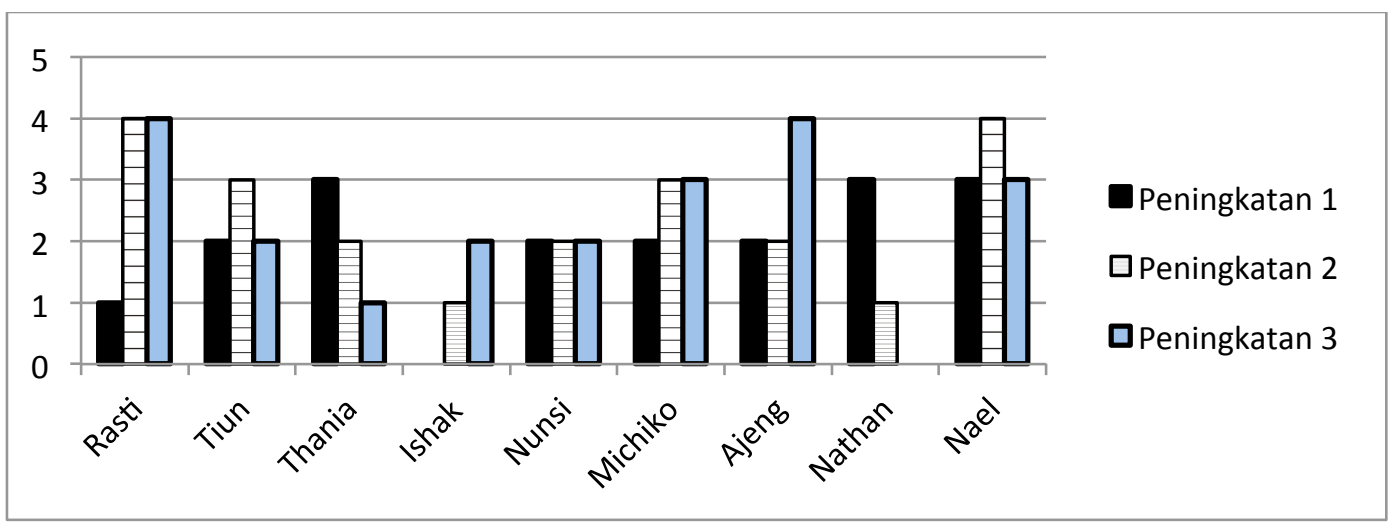

Gambar 8 Peningkatan Setelah Menggunakan Aplikasi pada Kelompok 1

Dalam pengujian aspek Task Success dan Time on Task, diberikan 6 jenis skenario yang berbeda yang digunakan partisipan ketika menggunakan aplikasi pembelajaran. Pengujian dilakukan kepada 9 partisipan yang telah menggunakan aplikasi sebanyak 3 kali. Partisipan diminta menggunakan aplikasi pembelajaran sesuai dengan skenario yang ada.

Berikut merupakan skenario yang diberikan kepada 9 partisipan:

- Task 1: menunjukkan materi hewan (kuda=horse)

- Task 2: menuju ke materi hewan selanjutnya

- Task 3: menuju ke materi hewan sebelumnya

- Task 4: mengulang kembali materi hewan

- Task 5: memilih menu permainan let's find fruit

- Task 6: memilih menu permainan let's find animal name

Dalam mengukur task success digunakan nilai biner, yaitu 1 untuk task yang sukses dan 0 untuk task yang gagal atau melebihi ukuran waktu yang telah ditentukan. Dengan menggunakan nilai biner maka lebih mudah untuk menetapkan nilai numeric sehingga dapat dengan mudah menghitung rata-rata. Hasil dari pengujian skenario pada kelompok 1, dapat dilihat pada tabel 3 .

Tabel 3.

Hasil Pengujian Skenario

\begin{tabular}{|c|c|c|c|c|c|c|c|}
\hline \multirow{2}{*}{ Nama } & \multicolumn{6}{|c|}{ Task Number } & \multirow{2}{*}{$\begin{array}{c}\text { Keberhasilan } \\
(\%) \\
\end{array}$} \\
\hline & 1 & 2 & 3 & 4 & 5 & 6 & \\
\hline Rasti & 1 & 1 & 1 & 1 & 1 & 0 & 83,33 \\
\hline Tiun & 1 & 1 & 1 & 1 & 0 & 1 & 83,33 \\
\hline Thania & 1 & 1 & 1 & 1 & 1 & 1 & 100 \\
\hline Ishak & 1 & 1 & 1 & 1 & 1 & 1 & 100 \\
\hline Nunsi & 1 & 1 & 1 & 1 & 0 & 0 & 66,67 \\
\hline Michiko & 1 & 1 & 1 & 1 & 0 & 0 & 66,67 \\
\hline Ajeng & 1 & 1 & 1 & 0 & 1 & 1 & 83,33 \\
\hline Nathan & 1 & 1 & 1 & 1 & 1 & 1 & 100 \\
\hline Nael & 1 & 1 & 1 & 1 & 1 & 1 & 100 \\
\hline Usability Sistem(\%) & 100 & 100 & 100 & 88,89 & 66,67 & 66.67 & 87,03 \\
\hline
\end{tabular}

Aspek Time on Task digunakan untuk mengukur sebanyak waktu yang diperlukan untuk menyelesaikan tugas. Hasil dari pengujian aspek Time on Task pada kelompok 1 dapat dilihat pada tabel 4 . 
Tabel 4.

Hasil Pengujian Time on Task

\begin{tabular}{|l|c|c|c|c|c|c|}
\hline \multirow{2}{*}{ Partisipan } & \multicolumn{7}{|c|}{ Task Time (second) } \\
\cline { 2 - 7 } & $\mathbf{1}$ & $\mathbf{2}$ & $\mathbf{3}$ & $\mathbf{4}$ & $\mathbf{5}$ & $\mathbf{6}$ \\
\hline Rasti & 30 & 1 & 1 & 1 & 15 & - \\
\hline Tiun & 16 & 1 & 1 & 1 & - & 34 \\
\hline Thania & 28 & 1 & 1 & 1 & 38 & 14 \\
\hline Ishak & 5 & 1 & 1 & 1 & 7 & 5 \\
\hline Nunsi & 11 & 2 & 2 & 2 & - & - \\
\hline Michiko & 25 & 1 & 1 & 2 & - & - \\
\hline Ajeng & 18 & 1 & 1 & - & 13 & 13 \\
\hline Nathan & 4 & 1 & 1 & 1 & 5 & 4 \\
\hline Nael & 10 & 1 & 1 & 1 & 11 & 12 \\
\hline Rata-rata & 16.33 & 1.11 & 1.11 & 1.25 & 15,17 & 14,17 \\
\hline
\end{tabular}

Pengujian usability dilakukan menggunakan teknik USE Questionaire, aspek yang diukur adalah kemudahan penggunaan sistem (Easy of use) dan kepuasan pengguna (Satisfaction). Pertanyaan yang diberikan kepada partisipan adalah sebagai berikut:

1. Easy of use

P1. Apakah aplikasi ini mudah digunakan?

P2. Apakah adik dapat menggunakan aplikasi ini tanpa bantuan kaka?

P3. Apakah adik-adik tahu arti dari tombol-tombol ini?

2. Satisfaction

P1. Menurut adik aplikasi ini menyenangkan tidak?

P2. Apakah aplikasi ini tidak membosankan?

P3. Adik ingin punya aplikasi ini di rumah tidak?

Tabel 5

Hasil Skala Likert dari Aspek Easy of Use

\begin{tabular}{|c|l|c|c|c|}
\hline No. & \multicolumn{1}{|c|}{ Nama } & P1 & P2 & P3 \\
\hline 1. & Rasti & 3 & 1 & 3 \\
\hline 2. & Tiun & 3 & 3 & 3 \\
\hline 3. & Thania & 3 & 3 & 3 \\
\hline 4. & Ishak & 3 & 1 & 3 \\
\hline 5. & Nunsi & 3 & 1 & 3 \\
\hline 6. & Michiko & 3 & 1 & 3 \\
\hline 7. & Ajeng & 3 & 3 & 1 \\
\hline 8. & Nathan & 3 & 3 & 3 \\
\hline 9. & Nael & 3 & 3 & 3 \\
\hline
\end{tabular}

Tabel 4.9

Hasil Skala Likert dari Aspek Satisfaction

\begin{tabular}{|c|l|c|c|c|}
\hline No. & \multicolumn{1}{|c|}{ Nama } & P1 & P2 & P3 \\
\hline 1. & Rasti & 3 & 3 & 3 \\
\hline 2. & Tiun & 3 & 3 & 3 \\
\hline 3. & Thania & 3 & 3 & 3 \\
\hline 4. & Ishak & 3 & 3 & 3 \\
\hline 5. & Nunsi & 3 & 3 & 3 \\
\hline 6. & Michiko & 3 & 3 & 3 \\
\hline 7. & Ajeng & 3 & 3 & 3 \\
\hline
\end{tabular}




\begin{tabular}{|l|l|l|l|l|}
\hline 8. & Nathan & 3 & 3 & 3 \\
\hline 9. & Nael & 3 & 3 & 3 \\
\hline
\end{tabular}

Pada table hasil interview, berisikan nilai 1 sampai 3 yang artinya yaitu $1=$ tidak setuju, 2 = biasa saja, 3 = setuju. Untuk menghitung penilaian partisipan terhadap aplikasi terhadap aspek-aspek yang diujikan. Maka dilakukan perhitungan dengan menghitung rata-rata tiap aspek. Hasil dari nilai rata-rata yang telah diperoleh kemudian dipetakan ke rentang skala dengan interval sebagai berikut:

$$
\text { interval }=\frac{\text { nilai terting } \text { i }- \text { nilai terendah }}{\text { banyaknya kelas }}=\frac{3-1}{3}=0,67
$$

Setelah besarnya interval diketahui, kemudian dibuat rentang skala sehingga dapat diketahui dimana letak rata-rata penilaian partisipan terhadap aplikasi. Rentang skala tersebut adalah sebagai berikut:

$1,00-1,66$ : buruk

$1,67-2,33$ : biasa saja

$2,34-3$ : baik

\begin{tabular}{|c|l|l|}
\hline No. & \multicolumn{1}{|c|}{ Aspek yang Diuji } & \multicolumn{1}{c|}{ Rata-rata } \\
\hline 1. & Easy of Use & 2,63 \\
\hline 3. & Satisfacition & 3 \\
\hline
\end{tabular}

\section{Kesimpulan}

Berdasarkan penelitian terhadap permainan edukasi kosakata nama hewan dan buah dalam bahasa Inggris, kesimpulan yang didapat antara lain:

1. Berdasarkan perbandingan hasil percobaan sebelum dan sesudah menggunakan aplikasi dengan partisipan sebanyak 18 anak, didapatkan peningkatan rata-rata sebanyak 2 pertanyaan yang dijawab dengan benar dari total 20 pertanyaan setelah partisipan menggunakan aplikasi. Hal ini menunjukkan bahwa permainan edukasi yang dibuat membantu pengguna untukmeningkatkan jumlah kosakata nama hewan dan buah dalam bahasa Inggris yang mampu diingat.

2. Berdasarkan pengujian usability menggunakan USE Questionare dengan partisipan sebanyak 9 anak, pada aspek Easy of Use didapatkan hasil bahwa partisipan menilai aplikasi ini termasuk dalam kategori baik, yaitu dengan rata-rata 2,63 (rentang 2,34 - 3). Hal ini menandakan bahwa apikasi yang dibuat mudah digunakan. Pada aspek Satisfaction didapatkan hasil bahwa partisipan menilai aplikasi ini termasuk dalam kategori baik, yaitu dengan rata-rata 3 (rentang 2,34-3). Hal ini menandakan bahwa aplikasi yang dibuat menyenangkan.

3. Berdasarkan pengujian performance dengan menggunakan performance metrics dengan partisipan sebanyak 9 anak, pada aspek task success didapatkan hasil 87,03\%. Pada tugas 1, 2, dan 3 diperoleh hasil $100 \%$, pada tugas 3 diperoleh hasil $88,89 \%$, pada tugas 5 dan 6 diperoleh hasil 66,67\%. Pada aspek task on time pada tugas pertama, diperoleh rata-rata 16 detik untuk menyelesaikan skenario pertama. Pada tugas kedua diperoleh rata-rata 1 detik untuk menyelesaikan skenario kedua. Pada tugas ketiga diperoleh rata-rata 1 detik untuk menyelesaikan skenario ketiga. Pada tugas keempat diperoeleh rata-rata 2 detik untuk menyelesaikan skenario keempat. Pada tugas kelima diperoleh rata-rata 28 detik untuk menyelesaikan skenario kelima. Pada tugas keenam diperoleh rata-rata 26 detik untuk menyelesaikan skenario keenam.

\section{Daftar Pustaka}

Adams, E., \& Rollings, A. (2007). Fundamentals of Game Design. New Jersey: Pearson Education, Inc.

Alan, C., Reimann, R., \& Cronin, D. (2007). About Face 3: The Essentials of Interaction Design. Indianapolis: Wiley Publishing.

Christina, N. W. (2010). English for Kinder Garden Students. Jakarta: Talenta Media Utama. 
Dale, E., \& Bamman, A. (1971). Techniques of Teaching Vocabulary. Field Educational Publications.

Galitz, W. O. (2007). The Essential Guide to User Interface Design An Introduction to GUI Design Principles and Techniques. Indiana: Wiley Publishing.

Handriyantini, E. (2009). Permainan Edukatif (Educational Games) Berbasis Komputeruntuk Siswa Sekolah Dasar.

Hurd, D., \& Jenuings, E. (2009). Standardized Educational Games Ratings: Suggested Criteria.

Kosasih, E., \& Suyono, A.H. (1998). Kapan Anak Belajar Bahasa Inggris.

Krug, S. (2005). Don't Make Me Think: A Common Sense Approach to Web Usability. Indianapolis: New Rides.

Mamahit, F., L.. (2013). Rancangan Aplikasi Media Pembelajaran Perhitungan Aritmatika untuk Kelas 2 $S D$.

Nielsen, J. (2003). Usability 101: Fundamentals and Definition - What, Why, How.

Nugraha, Ali. (2008). Kurikulum dan Bahan Belajar TK, Jakarta Universitas Terbuka.

Preece, J. (1994). Human-Computer Interaction. Addison Wesley, 66-75.

Rubin, \& Jefry. (2008). Handbook of Usability Testing: How to Plan, Design, and Conduct Effective Test. Canada: Wiley \& Sons.

Sigit, Bambang, \& Joko. (2008). Pengembangan Pembelajaran dengan Menggunakan Multimedia Interaktif untuk pembelajaran Yang Berkualitas. Semarang. Makalah Lomba Karya Tulis Ilmiah UNESS.

Sugiharto, Setiawan, J.R., Anita, N. (2011). Analisis Dan Perancangan Game Edukasi Pada TK Tarsisius II. Tesis. Jakarta: Binus University.

Suryadi. (2011). Kiat Jitu dalam Mendidik Anak. Diakses 1 Maret 2014, dari http://www.smashingmagazine.com

Tulis, T., \& Albert, B. (2008). Measuring The User Experience. Burlington: Morgan Kauffman.

Lidwell, W., Holden, K., \& Butler, J. (2003). Universal Principles of Design. Beverly, Mass. : Rockport Publishers.

Wulandari, E. (2010). Perancangan Game Edukasi Untuk Melatih Keterampilan Listening “Fun English With Audy" Menggunakan Macromedia Director. Sekolah Tinggi Manajemen Informarika dan Komputer AMIKOM.

http://www.ppt-backgrounds.net/wp-content/uploads/2013/11/Agriculture-Farm-Fence-PPTBackgrounds-1000x750.jpg

http://fc09.deviantart.net/fs70/f/2012/177/b/7/happy_farm_landscape_by_henry_design-d54wka6.png Diakses pada tanggal 30 Mei 2014.

http://monkeyplad.blogspot.com/ Diakses pada tanggal 30 Mei 2014.

http://rentedmule.info/wp-content/uploads/2013/01/pond.jpg Diakses pada tanggal 30 Mei 2014.

http://fc05.deviantart.net/fs70/i/2012/191/5/2/picnic_scene_by_erockertorres-d560ydd.png Diakses pada tanggal 30 Mei 2014.

http://image.yaymicro.com/rz_1210x1210/0/ec8/vector-picnic-tablecloth-and-empty-plate-ec8344.jpg Diakses pada tanggal $3 \overline{0}$ Mei 2014.

http://2.bp.blogspot.com/dL3qKO3Zd7M/TlcZYcEfGRI/AAAAAAAAADc/RjQx2GzW3QE/s1600/Picn ic\%2BBasket.png Diakses pada tanggal 30 Mei 2014.

http://us.123rf.com/450wm/iimages/iimages1303/iimages130301503/18549427-illustration-of-a-fruitvendor-stall-on-a-white-background.jpg Diakses pada tanggal 30 Mei 2014.

http://www.clipartbest.com/cliparts/9cR/5Ga/9cR5Gabce.jpeg Diakses pada tanggal 30 Mei 2014.

http://www.flannelrabbit.com/blog/wp-content/uploads/2009/10/BananaTreeLg.jpg Diakses pada tanggal 30 Mei 2014.

http://sweetclipart.com/multisite/sweetclipart/files/banana_tree.png Diakses pada tanggal 30 Mei 2014.

http://images.vectorimagesfree.com/2011/12/grapevine-vector0.jpg Diakses pada tanggal 30 Mei 2014.

http://1.bp.blogspot.com/FieHyTBTrRs/Uln5h_jmmKI/AAAAAAAAPe0/Hr1 fMbEwa_Q/s1600/116how-to-draw-mango-tree-for-kids.gif Diakses pada tanggal 30 Mei 2014.

http://us.123rf.com/400wm/400/400/kornilov14/kornilov141106/kornilov14110600016/9718152-grapevine.jpg Diakses pada tanggal 30 Mei 2014.

http://soundfxnow.com/animal/page/3/ Diakses pada tanggal 30 Mei 2014.

http://www.shutterstock.com/pic-51114871/stock-vector-cute-bear-with-honey-vector.html Diakses pada tanggal 24 April 2014.

http://www.shutterstock.com/pic-58856347/stock-vector-cute-cat-vector.html Diakses pada tanggal 24 April 2014.

http://www.shutterstock.com/pic-56628709/stock-vector-cute-chicken-and-chick-vector.html Diakses pada tanggal 24 April 2014. 
http://www.shutterstock.com/pic-56805109/stock-vector-cute-cow-vector.html Diakses pada tanggal 24 April 2014.

http://www.shutterstock.com/pic-59287369/stock-vector-a-cute-dog-crouching-in-the-ground-vector.html Diakses pada tanggal 24 April 2014.

http://www.shutterstock.com/pic-56628712/stock-vector-cute-duck-vector.html Diakses pada tanggal 24 April 2014.

http://www.shutterstock.com/pic-56197543/stock-vector-cute-elephant-vector.html Diakses pada tanggal 24 April 2014.

http://www.shutterstock.com/pic-71381443/stock-vector-head-frog-cartoon-character.html Diakses pada tanggal 24 April 2014.

http://www.shutterstock.com/pic-51114904/stock-vector-cute-horse-vector.html Diakses pada tanggal 24 April 2014.

http://www.shutterstock.com/pic-125468366/stock-vector-cartoon-illustration-of-a-circus-lion-jumpingthrough-hoop-sideview.html Diakses pada tanggal 24 April 2014.

http://www.shutterstock.com/pic-56773624/stock-vector-cute-pig-vector.html Diakses pada tanggal 25 April 2014.

http://www.shutterstock.com/pic-59359369/stock-vector-a-cute-rabbit-carrying-a-carrot-with-its-teethvector.html Diakses pada tanggal 25 April 2014.

http://www.shutterstock.com/pic-56773624/stock-vector-cute-pig-vector.html Diakses pada tanggal 25 April 2014.

http://www.shutterstock.com/pic-56837440/stock-vector-cute-sheep-vector.html Diakses pada tanggal 25 April 2014.

https://www.flickr.com/photos/fruitycuties Diakses pada tanggal 26 April 2014.

https://www.flickr.com/photos/fruitycuties/ Diakses pada tanggal 26 April 2014.

http://www.animal-sounds.org/air-animal-sounds.html Diakses pada tanggal 1 Juni 2014.

http://www.animal-sounds.org/farm-animal-sounds.html Diakses pada tanggal 1 Juni 2014.

http://www.animal-sounds.org/jungle-animal-sounds.html Diakses pada tanggal 1 Juni 2014.

http://www.animal-sounds.org/farm-animal-sounds.html Diakses pada tanggal 1 Juni 2014.

http://soundfxnow.com/animal/page/3/ Diakses pada tanggal 1 Juni 2014. 